\title{
Enzyme compositions in biological processes of animals to obtain environmentally friendly products
}

\author{
Inna Ivanova ${ }^{1}$, Olga Kovaleva, ${ }^{1, *}$, Julia Karmatskikh², Sergey Koshelev², Vladislav \\ Neverov $^{3}$, and Vera Trigub $^{3}$ \\ ${ }^{1}$ Tyumen State Agricultural Academy, 625003, Ulitsa Respubliki, 7, Tyumen, Tyumen Oblast, Russia \\ ${ }^{2}$ T. S. Maltsev Kurgan State Agricultural Academy, Russia, 641300 Kurgan region, Ketovsky district, \\ Lesnikovo village \\ ${ }^{3}$ Industrial University of Tyumen, 625000, Tyumen, Volodarsky str., 38, Russia
}

\begin{abstract}
The urgency of the investigated problem is due to the fact that enzymatic compositions in the diets of agricultural mammals contribute to better digestion of nutrients, which allows increasing the rate of inexpensive raw materials 'rich' in anti-nutritional factors without compromising the health and productivity of the animal. The article is aimed at researching the digestibility of nutrients and the effect of enzyme compositions on the productivity of cows, and on the analysis of changes in live weight and average daily increments, slaughter and meat qualities of experimental young fattening pigs. The leading method of study is conducting scientific, economic and physiological experiments. Studies allow revealing the effects of enzyme compositions on the gastrointestinal tract microflora, which will directly affect the digestibility of nutrients and productive qualities. The digestibility ratios of feed nutrients were greater in the animals of the experimental groups receiving the enzyme compositions. In cows, milk production increased, and milk composition improved. In the experimental groups of pigs, there was an increase in live weight and average daily growth; a high yield of meat was obtained and the best ratio of meat to fat was observed. The results can be used to study metabolic processes in animals.
\end{abstract}

\section{Introduction}

The development of biology in the second half of the twentieth century led to its close and fruitful unification not only with chemistry but also with physics in solving a number of poignant issues. The application of ideas and methods of modern physics in biology proved very useful, and now the physics of enzymes (proteins that act as catalysts in biochemical processes) is an important section of molecular biophysics, inextricably linked with biochemistry and enzymology [1].

\footnotetext{
${ }^{*}$ Corresponding author: lemur.84@mail.ru
} 
As established in recent years, specific enzymes called allosteric determine the regulation of multistage biochemical processes through feedbacks. Cybernetic processes in the cell - storage and transmission of information, regulation and control - are of chemical nature, implemented at the molecular level of the system. This way, a living cell and an organism differ from any modern machines, since all the cellular chemical reactions go with the indispensable participation of enzymes, and their importance in biology cannot be overestimated [2-3].

Examples of dissolved enzymes are proteolytic enzymes in the digestive system, examples of enzymes in condensed structures are cytochromes in mitochondria and myosin in muscle fibers.

The use of enzyme preparations in animal feeding pursues several goals. First, they neutralize the 'anti-nutritional factors' contained in such types of grain as wheat, rye, barley; second, they increase the availability of energy exchange due to the breakdown of carbohydrates which are usually not digested; third, they increase the availability of essential amino acids.

Realization of the genetic potential of farm animals is determined, first of all, by the full value of feeding. The main indicator of this complex is its balance in accordance with the needs of animals under certain physiological conditions and levels of productivity.

Feed enzymes help realize the genetic potential of animals, splitting substrates for the hydrolysis of which enzymes in the digestive tract are absent altogether or are present in a limited number. In this case, the activity of their endogenous ferments in the gastrointestinal tract can be supplemented [4-5].

Enzymes as biological catalysts of protein nature are capable of accelerating biochemical reactions in the body. The non-protein component of feed enzymes includes metal ions such as calcium, magnesium, zinc, cobalt, manganese or the vitamin portion which promote the manifestation of enzymatic activity.

In the digestive tract of mammals, hydrolytic enzymes play a key role in the process of digesting food. Their presence and activity determines such an important indicator of the diet as digestibility (the degree of use of nutritious food substances from feed).

The most promising are enzyme preparations containing amylases, proteinases, cellulases, p-glucanases, xylanase, pectatranseliminase [6].

The raw materials for the production of mixed fodder (traditional in this country) wheat, rye, barley, oats, bran - contain from 10 to $35 \%$ non-starch polysaccharides (NSP) in dry matter. These saccharides are practically not digested, since in the digestive secrets of animals there are no enzymes for their hydrolysis [7-8].

Due to feed enzymes, it is possible to influence one or several difficult-to-digest components of feeds present in the diet.

Because of the use of enzymes, animals receive additional nutrients, so the livestock becomes more homogeneous in terms of live weight and productivity [9].

The inclusion of enzymes in diets of mammals also reduces the release of nitrogen, phosphorus and trace elements with excrement due to better digestibility of their feed, which positively affects the ecological state of ecosystems.

The use of enzyme preparations in animal husbandry in combination with other biologically active substances is a most promising direction in the field of increasing feed resources efficiency [10].

According to Morozova L., Mikolaychik I. (2020), and others, in animals body these nutrients are converted into energy and structural materials necessary for growth and reproduction, the formation of products and the implementation of other life processes only through enzymes. The inclusion of enzymes promotes better digestibility of nutrients in the diet and reduces feed costs for production by $6-8 \%$ [11]. 
The main tasks of biotechnology in animal husbandry are the following studies of microorganisms as biological regulators of metabolic processes in the body of agricultural animals and poultry for the gradual abandonment of the preventive use of feed antibiotics (growth stimulators) in growing young animals and obtaining livestock products [12-13].

At present, practical importance is given to the microbiology of cattle rumen. Over the past 10 years, many farms in Russia achieved a high growth in animal productivity, mainly due to a large share of mixed feeds in the diet. Therefore, the rumen microflora is disrupted, which leads to a number of negative consequences, and productivity growth is accompanied by an equally rapid reduction in productive longevity. The increase in the cost of grain and mixed feeds complicates the work of zootechnicians in almost all highly productive farms [14-15].

It is known that about $30-40 \%$ of organic matter supplied with food is not digested by animals. When choosing enzyme preparations, it is necessary to take into account the degree of the enzyme system development and the features of animal digestion, the properties of the ferment preparations and their manifestations under the given conditions [16-17].

Therefore, the study in the nutrition of farm mammals of enzyme compositions which promote better digestion of incoming nutrients is a topical issue.

The aim of study was to analyze the use of enzyme compositions in the nutrition of cattle and pigs.

Objectives of study:

1. To establish the effect of enzyme compositions in animal feeding diets on the nutrient digestibility;

2. To study the effect of enzyme compositions on the productivity of cows;

3. To analyze growth, slaughter and meat qualities of the experimental fattening piglets.

\section{Materials and Methods}

It is known that large reserves of increasing livestock production lie in increasing the efficiency of animal feed based on the internal biological processes of the body. The present research is devoted to the effect of enzyme preparations on the microflora of the gastrointestinal tract of animals, which will directly affect the productive qualities.

To study the use of enzyme compositions in the nutrition of cattle and pigs, scientific, economic and physiological experiments were carried out.

Studies on the effectiveness of enzyme compositions to improve the digestibility of rations and, therefore, meat productivity in pigs during fattening and milk productivity in cows were conducted at the Federal State Unitary Enterprise 'Training and Experimental Farm' at Northern Trans-Ural State Agricultural University, currently one of the best educational facilities in Russia. The farm is located in the central part of the Tyumen region. This is a state multi-branch enterprise with the main directions of development being dairy cattle breeding. In 2016, a yield for a forage cow was 7,743 $\mathrm{kg}$ of milk with fat content of $3.85 \%$ and protein content of $3.08 \%$.

Dairy cows were divided into 10 heads according to the principle of analogue pairs taking into account their physiological status, origin, calving date, age, live weight, daily milk yield and fat content in milk. The animals were tied up in the same room with the same conditions; milking and feeding were done three times.

The cows of the control group received an economic diet consisting of $35 \mathrm{~kg}$ of feed mix and $8.5 \mathrm{~kg}$ of concentrated feed. The mix consisted of: silage, haylage, hay, and flattened grain. The composition of concentrated feed of domestic production was as follows: $50 \%$ wheat, $35 \%$ oats and $15 \%$ peas. 
The animals of the control group were fed the main economic ration while the cows of experimental group No. 1 were also administered an enzyme composition of domestic production 'TselloBacterin' in the amount of $25 \mathrm{~g}$ which contained a natural complex of living bacteria promoting better digestion of cellulose. The enzyme composition fulfilled the functions of two feed additives: feed enzyme and probiotic promoting increase in cellulolytic activity in the rumen up to $20 \%$, and increasing the consumption of coarse feed.

The cows of experimental group No. 2 were given an enzyme composition 'Fibrozaim' $(15 \mathrm{~g})$. The complex of 'protected' cellulases and hemicellulases starts working throughout the gastrointestinal tract after the rumen. The preparation is obtained by fermenting the cultures of Aspergillus niger and Trichoderma longibrachiatum.

The conditions of keeping, feeding and drinking, the microclimate parameters in all the groups were identical and corresponded to the daily routine of the farm.

Individual accounting of milk productivity was carried out according to control milking conducted twice a month. Based on control milking, the milk production was determined for 100 days of lactation and for lactation as a whole (305 days). The fat, protein and dry skimmed solids content was studied with the help of Milkoscan-50 based on the effects of infrared radiation (Foss-electrics, France).

In line with scientific and economic experiments, physiological studies were carried out to determine the digestibility of nutrients in rations and to study the state of energy, nitrogen, and mineral metabolism developed by All-Russian Research Institute of Animal Husbandry.

Chemical analysis of feeds, their residues, urine and feces was carried out according to the methods described by P.T. Lebedev and A.T. Usovich (1976). The dry matter content was detremined by drying, ash by burning in a muffle furnace at a temperature of 450 $500^{\circ} \mathrm{C}$, total nitrogen by the Kjeldahl method, raw fiber by Henneberg and Stohmann, raw fat by Soxhlet, nitrogen-free extractives substances by calculation, calcium by oxalate method, phosphorus by the intensity of phosphor-molybdenum blue, energy value of feeds by calculation.

The effect of the enzyme preparation 'Kemzaim W' was studied in monogastric animals, namely, pigs.

To accomplish this goal, scientific and economic experiment was conducted on pigs of large white breed at the age of 2-8 months. By the principle of analogues, 3 groups of 8 heads were formed. The control group of piglets received the basic diet, 1 and 2 experimental groups received, in addition to the main diet, $0.5 \mathrm{~kg} /$ ton and $1.0 \mathrm{~kg} /$ ton of the multienzyme composition 'Kemzaim W', respectively.

The pigs after weaning were fed 3 times a day for 12-15 days, then 2 times a day with a dry feed mix.

Meat fattening was carried out in 2 periods: preliminary from 3 to 5.5 months to a living weight of 55-60 kg; second (final) before removal from fattening. To assess the meat quality of animals, a control slaughter of 8 heads from each group was carried out at 8 months. This took into account pre-bodily live weight, the mass and yield of carcass, the mass of internal fat, the slaughter mass and the slaughter yield. The morphological composition of individual natural anatomical parts and the whole carcass was established by boning the right side cooled for 24 hours at a temperature from -2 to $+4{ }^{\circ} \mathrm{C}$. For the chemical analysis, the average pulp samples weighing $400 \mathrm{~g}$ and fat samples weighing 200 $\mathrm{g}$ were selected. 


\section{Results}

Cows were fed by detailed standards in accordance with the level of daily milk yield, fat content in milk and live weight of cows [18-19].

Feed intake in the animals of the experimental groups was 93.7 and $95.3 \%$, in the control group $-88.9 \%$ of the daily quantity.

The digestibility ratios of feed nutrients were greater in animals of 1 and 2 experimental groups. Compared with the control group cows, they digested more dry matter by 1.7 and $7.3 \%$; organic matter by 2.07 and $4 \%$; crude protein by 2.5 and $6.06 \%$; raw fat by 2.96 and $8.5 \%$; raw fiber by 2.94 and $5 \%$; biologically active substances by 1.9 and $3.2 \%$ respectively. Increase in digestibility of nutrients, especially fat (by 2.96-8.5\%), in comparison with the control group is explained by enzyme preparations that activate digestive processes in cattle rumen. It should be noted that in studies, the digestibility ratios of nutrients are quite high, which means the diet composition has a positive effect.

Thus, it can be concluded the cows of the experimental groups who received enzyme additives with hydrolyzing ability and a wide range of enzymes that act on practically all the nutrients of the ration, digested the organic substance and the 'raw' substances protein, fat, cellulose, biologically active substances - better than the control ones. The feed additive has a positive effect on digestion in the stomach of ruminants, and this served as an additional source of energy for the formation of milk.

The full value of milk is due to the presence of nutrients necessary for life. Full proteins, carbohydrates, minerals, including microelements, vitamins, enzymes and hormones are absorbed by the body almost completely: proteins by $96 \%$, fats by 95 , carbohydrates by $98 \%$.

The problem of improving the quality of milk is now highly relevant, so many factors that contribute to the increase in the total amount of dry matter, fat, proteins, sugar, minerals and vitamins should be studied.

Dairy productivity is one of the criteria that allows assessing the balance and usefulness of feeding cows during the experimental period (100 days), as well as the productive effect of supplements.

Studies reveal that the cows of the experimental group that received the enzyme complexes were more effective in using the nutrients of the ration for the synthesis of milk (Table 1).

Table 1. Milk productivity of cows for the first 100 days of lactation

\begin{tabular}{|l|c|c|c|}
\hline \multirow{2}{*}{\multicolumn{1}{|c|}{ Index }} & \multicolumn{3}{c|}{ Group } \\
\cline { 2 - 4 } $\begin{array}{l}\text { Milk yield for 100 days of } \\
\text { lactation, kg: }\end{array}$ & control & 1 experimental & 2 experimental \\
\hline at natural fat content & $2207.91 \pm 74.63$ & $2328.37 \pm 76.86$ & \\
\hline at 4\% fat content & $1887.30 \pm 132.56$ & $2036.40 \pm 143.16$ & $2229.08 \pm 61.57$ \\
\hline Mass fraction of fat, \% & $3.41 \pm 0.15$ & $3.49 \pm 0.14$ & $3.55 \pm 0.07$ \\
\hline Mass fraction of protein,\% & $3.13 \pm 0.03$ & $3.16 \pm 0.03$ & $3.18 \pm 0.03$ \\
\hline Average daily milk yield, kg: & & & $25.12 \pm 0.67$ \\
\hline at natural fat content & $22.08 \pm 0.75$ & $23.28 \pm 0.77$ & $22.29 \pm 0.61$ \\
\hline at 4\% fat content & $18.87 \pm 1.33$ & $20.36 \pm 1.43$ & $89.16 \pm 2.46$ \\
\hline Mass fraction of fat, $\mathrm{kg}$ & $75.49 \pm 5.3$ & $81.46 \pm 5.73$ & $79.85 \pm 1.32$ \\
\hline Mass fraction of protein, $\mathrm{kg}$ & $69.01 \pm 2.06$ & $73.61 \pm 1.77$ & \\
\hline
\end{tabular}

During the first 100 days of lactation, cows from the 1 st experimental group gave $5.5 \%$ more milk with natural fat content, and cows from the 2 nd experimental group $13.8 \%$ more 
than the animals from the control group. In terms of $4 \%$ milk, the animals of the 1 st experimental group outperformed by $7.32 \%$, and of the 2 nd experimental group by $18.1 \%$.

The yield of milk fat in the 1st experimental group was $5.97 \mathrm{~kg}$, or $7.9 \%$ larger and in the $2 \mathrm{nd} 13.7 \mathrm{~kg}$, or $18.1 \%$ larger compared to the control group.

The milk analysis reveals a significant increase not only in the fat percentage but also in the milk protein level in the experimental groups (Table 2).

Table 2. Productivity of cows by lactation

\begin{tabular}{|l|c|c|c|}
\hline \multirow{2}{*}{\multicolumn{1}{|c|}{ Index }} & \multicolumn{3}{c|}{ Group } \\
\cline { 2 - 4 } & control & 1 experimental & 2 experimental \\
\hline 100 day yield & $2207.91 \pm 74.63$ & $2328.37 \pm 76.86$ & $2512.50 \pm 66.86$ \\
\hline 100 day yield & $6133.70 \pm 24.45$ & $6376.50 \pm 26.07$ & $6953.90 \pm 25.03$ \\
\hline Mass fraction of fat, \% & $3.45 \pm 0.13$ & $3.51 \pm 0.09$ & $3.49 \pm 0.07$ \\
\hline Mass fraction of fat, $\mathrm{kg}$ & $211.62 \pm 30.62$ & $223.81 \pm 27.01$ & $242.69 \pm 23.09$ \\
\hline Mass fraction of protein, \% & $3.14 \pm 0.02$ & $3.15 \pm 0.03$ & $3.17 \pm 0.05$ \\
\hline Yield per 1st lactation, $\mathrm{kg}$ & $6283.84 \pm 23.34$ & $6572.67 \pm 52.37$ & $7264.21 \pm 15.87$ \\
\hline Yield days & 314 & 320 & 323 \\
\hline Yield per 2nd lactation, $\mathrm{kg}$ & $6780.15 \pm 22.07$ & $6745.34 \pm 76.41$ & $6810.15 \pm 44.15$ \\
\hline Yield days & 331 & 327 & 321 \\
\hline
\end{tabular}

Analyzing the data of Table 2, it can be seen that for 305 days of lactation experimental group cows gave $3.81 \%$ and $11.8 \%$ (Group 1 and 2, respectively) more whole milk compared with the control group. It should be noted that the 1 st lactation from the control group gave $6283.84 \mathrm{~kg}$ of milk, from experimental Group 1 the amount was $6572.67 \mathrm{~kg}$, and from experimental Group 2 it was $7264.21 \mathrm{~kg}$. For the 2nd lactation the control group gave $0.53 \%$ more milk than experimental Group 1, but $0.44 \%$ less than experimental Group 2 .

To obtain the best results in the productivity of cows, it is necessary to use enzyme additives for a long time. In this case, the microflora is constantly corrected, maximum digestion of the feed is ensured, which makes it possible to more fully realize the genetic potential without health damage.

The cow's ration is aimed at maximizing milk production. A special feature of cows' metabolism in this physiological state of the body is the intensive synthesis of milk components..

The chemical composition of milk is complex, with 20 amino acids, 30 macro and microelements, 23 vitamins, 20 glycerides, 4 sugars, a number of hormones, enzymes, pigments, phosphatides, etc. From the point of view of physical chemistry, milk can be represented as a dispersed system consisting of dispersed medium (water) and dispersed phase (smallest particles, constituent parts of milk).

For the formation of $1 \mathrm{~kg}$ of milk, up to 600 liters of blood flows through the mammary gland of the cow. Synthesis of milk components is conditioned by the level and full value of feeding. In this regard, a deep chemical analysis of milk for fat content, protein, dry skim milk, as well as macro-, microelements, fatty acids, amino acids and vitamins was carried out. Table 3 gives data on the chemical composition of the milk from the experimental groups.

More enriched milk was obtained from the cows of the two experimental groups. At the same time, the energy value of milk compared to the control group was $0.03 \mathrm{MJ}$ larger. The energy requirements of animals depend on the amount of milk produced and the fat content in it. With an increase in milk yield, the fat content in milk also increases: in the control group, it was 3.41 , which is $0.08 \%$ less than in experimental Group 1 and $0.14 \%$ less than 
in experimental Group 2. The percentage of total protein increased by $1.5 \%$ in the $2 \mathrm{nd}$ experimental group and by $0.96 \%$ in the 1 st compared with the control group.

Table 3. Chemical composition of milk $(\mathrm{X} \pm \mathrm{Sx})$

\begin{tabular}{|l|c|c|c|}
\hline \multirow{2}{*}{\multicolumn{1}{|c|}{ Index }} & \multicolumn{3}{c|}{ Group } \\
\cline { 2 - 4 } & control & 1 experimental & 2 experimental \\
\hline Energy value, MJ & $3.01 \pm 0.02$ & $3.03 \pm 0.04$ & $3.04 \pm 0.04$ \\
\hline Dry matter,\% & $12.42 \pm 1.79$ & $12.50 \pm 0.29$ & $12.55 \pm 0.41$ \\
\hline Mass fraction of fat,\% & $3.41 \pm 0.15$ & $3.49 \pm 0.14$ & $3.55 \pm 0.07$ \\
\hline Mass fraction of protein,\% & $3.13 \pm 0.03$ & $3.16 \pm 0.03$ & $3.18 \pm 0.03$ \\
\hline Casein\% & $2.80 \pm 0.05$ & $2.8 \pm 0.05$ & $2.81 \pm 0.05$ \\
\hline Lactose,\% & $4.70 \pm 0.07$ & $4.69 \pm 0.07$ & $4.67 \pm 0.08$ \\
\hline Ash,\% $\%$ & $0.72 \pm 0.02$ & $0.72 \pm 0.01$ & $0.72 \pm 0.01$ \\
\hline pH & $6.61 \pm 0.36$ & $6.50 \pm 0.21$ & $6.56 \pm 0.31$ \\
\hline Acidity, ${ }^{\circ} \mathrm{T}$ & $16.8 \pm 1.31$ & $17.1 \pm 0.91$ & $16.9 \pm 0.50$ \\
\hline Density, ${ }^{\circ} \mathrm{A}$ & $30.14 \pm 0.45$ & $30.17 \pm 0.52$ & $29.97 \pm 0.59$ \\
\hline Dry skim milk, \% & $9.03 \pm 0.17$ & $9.01 \pm 0.13$ & $9.00 \pm 0.11$ \\
\hline
\end{tabular}

The ash content of all the three groups was at the same level of $0.72 \%$. It is dry matter that characterizes the nutritional value of milk, yet the difference in it between the cows of different groups was insignificant.

In the evaluation of milk quality, titratable and active acidity is distinguished. The titratable acidity of fresh milk is in the range of $16-18^{\circ} \mathrm{T}$, the active acidity ranges from $\mathrm{pH}$ 6.3 to 6.9 .

In experimental animals, the acidity was within the normal range. In the control group, the titratable acidity was $16.8^{\circ} \mathrm{T}$, in experimental Groups 1 and 2 it was 17.1 and $16.9^{\circ} \mathrm{T}$ respectively.

The problem of environmentally friendly produce requires solving complex issues, including improving the metabolism and finding ways to remove toxic metals from the body.

Mineral substances enter the organism of animals and pass into milk mainly from forages; they have an important physiological and technological significance in the processing of milk.

Table 4 contains data on the content of macro- and microelements, and of heavy metals in the milk of experimental cows.

Inclusion of the enzyme composition with cellulolytic action in the ration significantly increased the calcium content in experimental Group $2(\mathrm{P} \leq 0.05)$ by $8.51 \%$ compared with the control and by $4.44 \%$ - with experimental Group 1 . The phosphorus content changed insignificantly, so the animals of experimental Group 2 had more phosphorus in milk (by $0.04 \mathrm{~g} / \mathrm{kg}$ ) than the control and $0.03 \mathrm{~g} / \mathrm{kg}$ more than experimental Group $2(\mathrm{P} \leq 0.05)$. The level of potassium was more in the experimental groups on average by $3.97 \%$. The experimental groups had 1.51 and $1.54 \mathrm{~g} / \mathrm{kg}$, respectively, and the control group had 1.45 $\mathrm{g} / \mathrm{kg}$.

Table 4. Macro- $(\mathrm{g} / \mathrm{kg})$, micro-elements $(\mathrm{mg} / \mathrm{kg})$, heavy metals $(\mathrm{mg} / \mathrm{kg})$ in cow milk $(\mathrm{X} \pm \mathrm{Sx})$

\begin{tabular}{|l|c|c|c|}
\hline \multirow{2}{*}{ Minerals } & \multicolumn{3}{|c|}{ Group } \\
\cline { 2 - 4 } & control & 1 experimental & 2 experimental \\
\hline Calcium, g/kg & $1.29 \pm 0.04$ & $1.35 \pm 0.04$ & $1.41 \pm 0.05^{*}$ \\
\hline Phosphorus, g/kg & $0.94 \pm 0.01$ & $0.97 \pm 0.02^{*}$ & $0.98 \pm 0.02$ \\
\hline Potassium, g/kg & $1.45 \pm 0.05$ & $1.51 \pm 0.06$ & $1.54 \pm 0.04$ \\
\hline
\end{tabular}




\begin{tabular}{|l|c|c|c|}
\hline Sodium, g/kg & $0.37 \pm 0.02$ & $0.38 \pm 0.03$ & $0.38 \pm 0.02$ \\
\hline Magnesium, g/kg & $0.085 \pm 0.004$ & $0.084 \pm 0.001$ & $0.084 \pm 0.002$ \\
\hline Iron, $\mathrm{mg} / \mathrm{kg}$ & $0.65 \pm 0.03$ & $0.66 \pm 0.01$ & $0.69 \pm 0.03^{*}$ \\
\hline Manganese, $\mathrm{mg} / \mathrm{kg}$ & $0.23 \pm 0.02$ & $0.22 \pm 0.02$ & $0.24 \pm 0.03$ \\
\hline Copper, $\mathrm{mg} / \mathrm{kg}$ & $0.133 \pm 0.002$ & $0.130 \pm 0.003$ & $0.129 \pm 0.005^{*}$ \\
\hline Zinc, $\mathrm{mg} / \mathrm{kg}$ & $3.51 \pm 0.01$ & $3.50 \pm 0.06^{*}$ & $3.49 \pm 0.03$ \\
\hline Lead, $\mathrm{mg} / \mathrm{kg}$ & $0.027 \pm 0.003$ & $0.024 \pm 0.005$ & $0.025 \pm 0.003^{*}$ \\
\hline Cadmium, $\mathrm{mg} / \mathrm{kg}$ & $0.0048 \pm 0.0004$ & $0.0046 \pm 0.0011$ & $0.0039 \pm 0.0014$ \\
\hline
\end{tabular}

$$
* \mathrm{P} \leq 0.05
$$

The sodium content changed insignificantly and averaged $0.37 \mathrm{~g} / \mathrm{kg}$. There was a slight decrease in magnesium in the experimental groups by $0.001 \mathrm{~g} / \mathrm{kg}$ compared with the control. In the milk of experimental Group 2, the iron content was $0.69 \mathrm{mg} / \mathrm{kg}$, which is significantly more $(\mathrm{P} \leq 0.05)$ than in the control group and in experimental Group 1 - by $0.04 \mathrm{mg} / \mathrm{kg}(5.8 \%)$ and $0.03 \mathrm{mg} / \mathrm{kg}(4.3 \%)$, respectively. The manganese content changed insignificantly and averaged $0.23 \mathrm{mg} / \mathrm{kg}$. When introducing enzyme compositions into the diet, a slight decrease in the concentration of toxic elements in the milk of lactating cows is observed. Thus, the content of copper decreased in the experimental groups by 2.26 and $3.01 \%$, respectively, compared with the control group. Also, the zinc level was reduced by $0.01 \mathrm{mg} / \mathrm{kg}(0.28 \%)$ and $0.02 \mathrm{mg} / \mathrm{kg}(0.57 \%)$, lead by $0.003 \mathrm{mg} / \mathrm{kg}(11.1 \%)$ and 0.002 $\mathrm{mg} / \mathrm{kg}(7.4 \%)$, cadmium by $0.0002 \mathrm{mg} / \mathrm{kg}(4.17 \%)$ and $0.0009 \mathrm{mg} / \mathrm{kg}(18.75 \%)$, respectively, compared with the control group.

An important point in studying the quality of milk and especially the usefulness of protein is the content of amino acids in milk.

Replaceable amino acids found in animal tissue proteins can be synthesized by the body during metabolism in quantities that provide the body's need; these include alanine, glutamic and aspartic acid, hydroxyproline, serine, glycine, leucine, cystine, cysteine, and proline. Cystine and tyrosine are considered partially replaceable, since they can be synthesized from essential amino acids - methionine and phenylalanine, respectively. Essential amino acids cannot be synthesized in the body or formed quickly enough to meet its needs.

Consequently, supplying animals with amino acids will depend on the intake of methionine + cystine and phenylalanine + tyrosine with the feed. Table 5 gives data on the amino acid content in milk.

Table 5. Amino acid composition of milk $(\mathrm{g} / \mathrm{kg}),\left(\mathrm{X} \pm \mathrm{S}_{\mathrm{x}}\right)$

\begin{tabular}{|l|c|c|c|}
\hline \multirow{2}{*}{\multicolumn{1}{|c|}{ Index }} & \multicolumn{3}{c|}{ Group } \\
\cline { 2 - 4 } & control & 1 experimental & 2 experimental \\
\hline Leucine & $3.35 \pm 0.03$ & $3.45 \pm 0.07$ & $3.67 \pm 0.03^{*}$ \\
\hline Isoleucine & $1.63 \pm 0.02$ & $1.71 \pm 0.01$ & $1.79 \pm 0.03^{* *}$ \\
\hline Lysine & $2.77 \pm 0.04$ & $2.84 \pm 0.08$ & $2.95 \pm 0.01$ \\
\hline Valine & $2.25 \pm 0.03$ & $2.29 \pm 0.03^{*}$ & $2.34 \pm 0.04^{*}$ \\
\hline Methionine & $9.83 \pm 0.02$ & $9.75 \pm 0.06$ & $9.83 \pm 0.07$ \\
\hline Tryptophan & $0.57 \pm 0.08$ & $0.56 \pm 0.06$ & $0.56 \pm 0.04$ \\
\hline Threonine & $1.59 \pm 0.09$ & $1.63 \pm 0.11$ & $1.71 \pm 0.08^{*}$ \\
\hline Phenylalanine & $19.08 \pm 0.10$ & $18.89 \pm 0.07$ & $19.09 \pm 0.11$ \\
\hline Alanine & $13.34 \pm 0.08$ & $14.05 \pm 0.07$ & $14.11 \pm 0.06$ \\
\hline Glutamic acid & $80.97 \pm 0.06$ & $78.14 \pm 0.06$ & $79.64 \pm 0.13$ \\
\hline Histidine & $0.89 \pm 0.44$ & $0.93 \pm 0.02$ & $0.95 \pm 0.15^{*}$ \\
\hline Serine & $20.45 \pm 0.34$ & $19.23 \pm 0.22$ & $19.55 \pm 0.13$ \\
\hline
\end{tabular}




\begin{tabular}{|l|c|c|c|}
\hline Arginine & $25.25 \pm 0.16$ & $26.34 \pm 0.07$ & $25.26 \pm 0.09$ \\
\hline Proline & $33.06 \pm 0.06$ & $34.45 \pm 0.06$ & $34.78 \pm 0.33$ \\
\hline Glycine & $5.55 \pm 0.15$ & $5.57 \pm 0.06$ & $5.56 \pm 0.11$ \\
\hline Methionine + cystine & $1776.78 \pm 90.67$ & $1822.65 \pm 114.55$ & $1834.34 \pm 110.12$ \\
\hline $\begin{array}{l}\text { Phenylalanine } \\
\text { tyrosine }\end{array}$ & $305.56 \pm 23.78$ & $311.34 \pm 18.44$ & $315.23 \pm 35.43$ \\
\hline
\end{tabular}

$* \mathrm{P} \leq 0.05 ; * * \mathrm{P} \leq 0.01$

Table 5 shows that in the milk of the control group cows less leucine, isoleucine, lysine and valine is contained. The content of leucine, valine and threonine is significantly greater $(\mathrm{P} \leq 0,05)$ in the milk of experimental Group 2 as compared with the control and experimental Group $1-871 ; 3.85 ; 7.02 \%$ and 5.99; 4.47; 4.68\%, respectively. The content of tryptophan, serine and glutamine is higher in the control group compared with experimental Groups 1 and $2-1.75 ; 5.97 ; 3.96 \%$ and $1.75,4.40$ and $1.64 \%$, respectively.

Among the essential amino acids, three are particularly important: methionine, lysine and tryptophan. Methionine + cystine was higher in the 2 nd experimental group by $0.64 \%$ than in the $1^{\text {st }}$ experimental group and by $3.14 \%$ than in the control group.

Methionine regulates fat metabolism and prevents obesity of the liver. Lysine is closely related to hemopoiesis; the lack of it in food leads to the blood formation being disrupted and the number of red blood cells being reduced, and thus, the hemoglobin level decreases. If there is a lack of lysine in food, the exchange of nitrogen and calcification of bones are disrupted, muscles are depleted, and a number of changes occur in the liver and lungs.

Tryptophan is necessary for the synthesis of some important compounds (for instance, nicotinic acid and serotonin). Violations of its exchange can lead to dementia. In addition, metabolic disorders of tryptophan can serve as an indicator of diseases such as tuberculosis, cancer, diabetes, etc. The content of this essential amino acid in the control and in the experimental groups was at the same level.

Virtually all the vitamins necessary for the normal development of humans and animals are contained in milk. Most vitamins enter the animal's body with food and are synthesized by the rumen microflora. The content of vitamins in raw milk varies depending on the season, the stage of lactation, the rations of feeding, the breed and the individual characteristics of the cows. At the same time, the dependence of the vitamin content on the feed composition is more characteristic for fat-soluble vitamins than for water-soluble vitamins.

Vitamins are low-molecular compounds necessary for normal vital activity of humans, animals, plants and microorganisms. They play an important role in the metabolism, since many of them are part of the active groups of bicomponent enzymes. The lack of vitamins in food leads to a disruption of metabolism and ultimately to diseases. The vitamin composition of the milk in the experimental groups is presented in Table 6.

Analyzing the data given, it should be noted that the milk of the control group contained fewer vitamins. Thus, experimental Group 2 had more tocopherol and thiamine than the control and experimental Group $1-3.97 ; 5.08 \%$ and $3.97 \% ; 3.39 \%$, respectively $(\mathrm{P} \leq 0,05)$.

The content of vitamins $\mathrm{A}$ and $\mathrm{D}$ was similar in all the experimental groups. The content of vitamins $\mathrm{B}_{2}, \mathrm{~B}_{3}$ and $\mathrm{B}_{12}$ was larger in the 2 nd experimental group by $3.72 ; 3.67$; and $6.97 \%$, than in the control and by $2.12 ; 2.57 ; 5.86 \%$ than in experimental Group 1 , respectively. Pyridoxine (B6) is a part of coenzymes and a number of enzymes; it is essential for the growth of yeast and lactic acid bacteria, and was at the same level in all the three groups. 
Thus, including enzymatic compositions with cellulolytic action in cow diets had a positive effect on the amino acid and vitamin composition of milk. All the indicators were within physiological norms.

Table 6. Vitamin composition of milk, $\mathrm{g} / \mathrm{kg}(\mathrm{X} \pm \mathrm{x})$

\begin{tabular}{|l|c|c|c|}
\hline \multirow{2}{*}{\multicolumn{1}{|c|}{ Index }} & \multicolumn{3}{c|}{ Group } \\
\cline { 2 - 4 } & control & 1 experimental & 2 experimental \\
\hline $\mathrm{A}$ - retinol & $0.37 \pm 0.011$ & $0.37 \pm 0.004$ & $0.38 \pm 0.013$ \\
\hline $\mathrm{D}$ - calciferol & $0.50 \pm 0.016$ & $0.49 \pm 0.007$ & $0.51 \pm 0.008$ \\
\hline $\mathrm{E}$ - tocopherol & $1.21 \pm 0.031$ & $1.21 \pm 0.010$ & $1.26 \pm 0.019^{*}$ \\
\hline $\mathrm{B}_{1}$ - thiamine & $0.56 \pm 0.004$ & $0.57 \pm 0.009$ & $0.59 \pm 0.007^{*}$ \\
\hline $\mathrm{B}_{2}$ - riboflavin & $1.81 \pm 0.019$ & $1.84 \pm 0.011$ & $1.88 \pm 0.015^{*}$ \\
\hline $\mathrm{B}_{3}$ - pantothenic acid & $5.25 \pm 0.05$ & $5.31 \pm 0.11^{*}$ & $5.45 \pm 0.09$ \\
\hline $\mathrm{B}_{5}$ - nicotinic acid & $1.69 \pm 0.022$ & $1.73 \pm 0.019$ & $1.83 \pm 0.014$ \\
\hline $\mathrm{B}_{6}$ - pyridoxine & $0.24 \pm 0.007$ & $0.24 \pm 0.011$ & $0.25 \pm 0.009$ \\
\hline $\mathrm{B}_{12}-$ cyanocobalamin & $5.87 \pm 0.031$ & $5.94 \pm 0.013$ & $6.31 \pm 0.021$ \\
\hline
\end{tabular}

Determination of the economic efficiency of milk production allows making a conclusion about the advisability of using enzymatic additives of domestic and foreign production in cow rations at lactation. Thus, in the experimental groups, a yield of 305 days with a basic fat content per forage cow is more than in the animals in the control group - by $329.8(5.45 \%)$ and $839.95(12.81 \%)$. The costs are the same as in the case of lactation, and the additional profit from sales in the experimental groups is more by 2743.20 rubles $(17.51 \%)$ in the 1 st group and by $7274.55(36.03 \%)$ in the 2nd experimental group in comparison with control. It clearly reflects the economic efficiency $-33.50 \%$ in the control, $40.38 \%$ in experimental Group 1 and $51.98 \%$ in experimental Group 2.

The maximum productivity of pigs is achieved only when the correct breeding and maintenance are combined with sufficient feeding of animals during all the periods of their life. The main goal of the standardized feeding of pigs is to ensure the maximum, genetically determined productivity through the rational use of feeds while maintaining health and reproductive functions. Both inadequate and excessive feeding negatively affects not only the pigs, but also the economic indicators of the industry.

The zootechnical analysis carried out made it possible to determine the chemical composition of the grain mixture of own production (wheat, oats, peas, barley) in absolute dry matter and with natural moisture. Proceeding from this, the diets of the experimental animals were compiled in accordance with age, physiological condition, productivity, breed and maintenance conditions.

The piglets of the control group from 2 to 4 months were given: grain mixture $(88.9 \%)$, whole milk substitutes $(8.3 \%)$ and rape seed $(2.8 \%)$; from 5 to 8 months they were given only grain mixture $-30.5 \%$ wheat, $42.3 \%$ oats, $22.1 \%$ peas and $5.1 \%$ barley. The piglets of the two experimental groups received, in addition to the identical rations of the control group, respectively 0.5 and $1 \mathrm{~kg} /$ ton of multienzyme composition 'Kemzaim W' throughout the experiment.

During all the growth periods, in order to meet the requirements of pigs in sodium and chlorine, sodium chloride in the amount of $0.5 \%$ by weight was added to the rations.

One of the important reserves of increasing productivity and improving the quality of products is to increase the absorption of nutrients from the feeds used. Deficiency or excess nutrients in diets and their biological inferiority can cause depression of growth and development of animals. 
Biological inferiority of diets is accompanied by complex and peculiar changes in the functional state of all organs and systems, including the digestive tract. During this period, there are significant changes in the digestibility and use of nutrients in the diet.

The difference in the number of digested nutrients is unreliable $(\mathrm{P}<0.05)$. The average digestibility ratios of nutrients are presented in Table 7.

Table 7. Nutrient digestibility factors, $\%(\bar{X} \pm S \bar{x})$

\begin{tabular}{|l|c|c|c|}
\hline \multirow{2}{*}{\multicolumn{1}{|c|}{ Index }} & \multicolumn{3}{|c|}{ Group } \\
\cline { 2 - 4 } & control & 1 experiment & 2 experiment \\
\hline Dry matter & $81.07 \pm 0.50$ & $81.92 \pm 1.02$ & $83.91 \pm 0.69^{*}$ \\
\hline Organic matter & $82.99 \pm 0.31$ & $83.96 \pm 0.89$ & $85.65 \pm 0.75^{*}$ \\
\hline Crude protein & $80.09 \pm 0.5$ & $80.40 \pm 0.64$ & $82.36 \pm 1.50$ \\
\hline Crude fat & $76.69 \pm 1.01$ & $78.97 \pm 1.26$ & $84.08 \pm 0.89^{* *}$ \\
\hline Raw fiber & $47.37 \pm 1.77$ & $50.79 \pm 2.19$ & $57.73 \pm 0.83^{* *}$ \\
\hline Biologically active substances & $88.18 \pm 0.4$ & $88.96 \pm 1.25$ & $89.81 \pm 0.6$ \\
\hline
\end{tabular}

The data analyzed indicate that the digestibility of dry matter and organic matter improved in the piglets of the experimental groups receiving the multi-enzyme complex with feeds in comparison with the control group - the digestion coefficients were 0.85 and $0,97 \%$ higher in the 1 st experimental group and by 2.84 and $2.66 \%$ in the 2 nd, respectively $(\mathrm{P}<0.05)$

Animals of the two experimental groups also better digested raw protein, raw fat and crude fiber. For example, the coefficient of digestibility of crude protein was $0.31 \%$ and $2.27 \%$, of raw fat 2.28 and $7.39(\mathrm{P}<0.01)$, and of crude fiber 3.42 and $10.36 \%(\mathrm{P}<0.01)$, respectively; this is a greater level than in the control group. However, there were no significant differences in the digestibility of biologically active substances, although there was an increase in their digestibility in the experimental groups.

These data indicate that feeding piglets with the multi-enzyme composition 'Kemzaim $\mathrm{W}^{\prime}$ ' in the amount of $1 \mathrm{~kg} / \mathrm{t}$ positively influenced the digestibility of raw nutrients.

An important indicator in the study of growth and development is the dynamics of changes in live weight (Table 8) and in average daily growth, characterizing the degree of development of the organism during ontogeny.

The obtained data reveal that during the experimental period the animals of the 2 experimental groups receiving 'Kemzaim W' in the amount of $1 \mathrm{~kg} / \mathrm{t}$ had the largest live weight. At the end of the experiment, the live weight of the pigs in the 2 nd experimental group was more than in the 1 st by $5.3 \%$ and significantly $(\mathrm{P}<0.001)$ more than in the control group - by $7.9 \%$. Although in the 1 st experimental group the living weight is less than in the 2 nd, it significantly $(\mathrm{P}<0.05)$ exceeds the control group - by $3.6 \%$.

The average daily weight gain in the control group was $353 \mathrm{~g}$, which is 5.6 and $15.6 \%$ $(\mathrm{P}<0.001)$ less than in the 1 st and 2 nd experimental groups. The same increase in the average daily growth is observed in the second period and for the whole experiment. In general, the absolute increase was by $2.8 \%(\mathrm{P}<0.001)$ in the 1 st experimental group and by $9.2 \%$ in the 2 nd compared with the control. The difference in absolute growth between the experimental groups was $6.6 \%$, in favor of the 2 nd experimental group.

Thus, the use of the multi-enzyme composition 'Kemzaim W' in the amount of $1 \mathrm{~kg} / \mathrm{t}$ in the rations of young pigs positively influences the increase in live weight and average daily growth. 
Table 8. Dynamics of live weight and average daily weight gain of piglets, $\bar{X} \pm S \bar{x}$

\begin{tabular}{|l|c|c|c|}
\hline \multirow{2}{*}{ Index } & \multicolumn{3}{c|}{ Group } \\
\cline { 2 - 4 } & control & 1 experimental & 2 experimental \\
\hline Live weight, kg: & I period & \\
\hline at the beginning & $17.00 \pm 0.53$ & $17.13 \pm 0.51$ & $17.13 \pm 0.51$ \\
\hline at the end & $38.5 \pm 0.49$ & $39.9 \pm 0.32^{*}$ & $42.0 \pm 0.40^{* * *}$ \\
\hline Average daily gain, g & $353 \pm 8.76$ & $373 \pm 8.11$ & $408 \pm 6.14^{* * *}$ \\
\hline \multicolumn{4}{|c|}{ II period } \\
\hline Live weight at the end, kg & $105.5 \pm 0.86$ & $108.1 \pm 0.32^{*}$ & $113.8 \pm 0.39^{* * *}$ \\
\hline Average daily gain, g & $549 \pm 7.59$ & $560 \pm 3.31$ & $591 \pm 3.21^{* * *}$ \\
\hline \multicolumn{4}{|c|}{ The whole experiment } \\
\hline Gross increase, kg & $88.5 \pm 0.99$ & $90.97 \pm 0.70$ & $96.67 \pm 0.49^{* * *}$ \\
\hline Average daily gain, g & $484 \pm 5.41$ & $497 \pm 3.82$ & $528 \pm 2.69^{* * *}$ \\
\hline$\%$ of the control group & 100 & 102.7 & 109.1 \\
\hline
\end{tabular}

The nature of the absorption of nutrients in fattening pigs greatly affects the quality of the carcasses and the chemical composition of the tissues. Therefore, in order to study the meat productivity of the experimental pigs, a control slaughter was carried out for 3 heads from each group, followed by boning. The results are given in Table 9.

Table 9. Results of control slaughter of animals, $\bar{X} \pm S \bar{x}$

\begin{tabular}{|l|c|c|c|}
\hline \multirow{2}{*}{ Index } & \multicolumn{3}{c|}{ Group } \\
\cline { 2 - 4 } & control & 1 experimental & 2 experimental \\
\hline Pre-slaughter weight, kg & $101.0 \pm 1.22$ & $106.0 \pm 1.16^{*}$ & $109.0 \pm 1.02^{* *}$ \\
\hline Slaughter weight, kg & $66.7 \pm 0.63$ & $76.4 \pm 0.60^{* * *}$ & $77.0 \pm 0.57^{* * *}$ \\
\hline Weight of internal fat & $1.8 \pm 3.29$ & $1.9 \pm 1.11$ & $2.0 \pm 1.52$ \\
\hline Slaughter yield,\% & $66.0 \pm 0.89$ & $72.0 \pm 2.76$ & $71.0 \pm 0.71^{*}$ \\
\hline Length of carcass, cm & $99.0 \pm 0.32$ & $111.0 \pm 0.35^{* * *}$ & $102.0 \pm 0.28^{* *}$ \\
\hline $\begin{array}{l}\text { The area of the 'loin eye', } \\
\text { cm }^{2}\end{array}$ & $28.1 \pm 0.42$ & $30.8 \pm 1.36$ & $31.77 \pm 0.37^{* * *}$ \\
\hline $\begin{array}{l}\text { Thickness of fatback over } \\
\text { 6-7 thoracic vertebrae, mm }\end{array}$ & $43.0 \pm 0.70$ & $46.0 \pm 0.61$ & $47.0 \pm 0.59^{*}$ \\
\hline
\end{tabular}

The data of Table 9 shows that the highest effect on the increase in live weight, and consequently, on the weight of the fattening pigs, was due to the multi-enzyme composition. The live weight of the piglets before slaughter after fasting in the 1 st and 2nd experimental groups exceeded the control by $4.95(\mathrm{P}<0.05)$ and $7.9 \%(\mathrm{P}<0.01)$, respectively, the highest index being in the 2 nd experimental group.

The highest slaughter weight was in animals of the 2 nd experimental group $(77 \mathrm{~kg})-$ $15.4 \%(\mathrm{P}<0.001)$ more than in the control group and $0.8 \%$ than in the 1 st experimental group.

The slaughter yield in the control group was $6 \%(\mathrm{P}>0.05)$ lower than in experimental Group 1 and $5 \%(\mathrm{P}<0.05)$ lower than in experimental Group 2. The piglets of experimental Group 1 also had an advantage in the length of the carcass over the control group and the experimental Group $2-12.1 \%$ and $8.8 \%$, respectively.

The fatback thickness was higher in the 2 nd experimental group - by $9.3 \%(\mathrm{P}<0.05)$ compared with the control and by $2.2 \%$ compared with experimental Group 1 . 
To measure the meat productivity of pigs, the mean yields of individual tissues were calculated (Table 10).

Table 10. Composition of pig carcasses, $\bar{X} \pm S \bar{x}$

\begin{tabular}{|l|c|c|c|}
\hline \multirow{2}{*}{\multicolumn{1}{|c|}{ Index }} & \multicolumn{3}{c|}{ Group } \\
\cline { 2 - 4 } & control & 1 experimental & 2 experimental \\
\hline Weight of chilled carcass, kg & $60.98 \pm 0.71$ & $66.46 \pm 0.44^{* *}$ & $67.04 \pm 0.43^{* * *}$ \\
\hline Muscular tissue, kg & $34.65 \pm 0.42$ & $37.80 \pm 0.37 * * *$ & $39.23 \pm 0.54^{* * *}$ \\
\hline Fat tissue, kg & $18.72 \pm 0.29$ & $19.83 \pm 0.33^{* *}$ & $18.10 \pm 0.36^{*}$ \\
\hline Bone tissue, kg & $7.90 \pm 2.15$ & $8.83 \pm 1.11$ & $9.70 \pm 1.46$ \\
\hline $\begin{array}{l}\text { Ratio of tissues to carcass } \\
\text { mass, } \%\end{array}$ & & & \\
\hline Muscular & 56.82 & 56.87 & 58.52 \\
\hline Fat & 30.70 & 29.84 & 26.99 \\
\hline Bone & 12.96 & 13.29 & 14.47 \\
\hline
\end{tabular}

Table 10 shows that the largest mass of chilled carcass was significant in the animals of the 2nd experimental group $(67.04 \mathrm{~kg})$, which is $9.9 \%$ more $(\mathrm{P}<0.001)$ than in the control and $0.9 \%$ more than in the 1 st experimental group.

The highest yield of meat was obtained from carcasses of the 2 nd experimental group, $13.2 \%(\mathrm{P}<0.001)$ more than in the control. The yield of meat was higher in experimental Group 1 - by $9.1 \%$ compared to the control. The best ratio of meat to fat was also in the 2nd experimental group.

Thus, the multi-enzyme composition 'Kemzaim $\mathrm{W}$ ' in the amount of $1 \mathrm{~kg} / \mathrm{t}$ in the rations of young pigs positively influenced the digestibility of raw nutrients, the increase in live weight and average daily growth, the yield of meat, the quality of carcasses and the chemical composition of the tissues.

\section{Discussion}

Discussing the obtained results on multi-enzyme compositions in cow diets, an increase in milk productivity and in the fat content in milk was established.

The increase in fat content in milk can be explained by the introduction of an enzymatic additive containing cellulolytic bacteria in the diet, which has a positive effect on the productivity and fat content of milk when the main feed does not provide milking cows with these components.

Enzymes in nature are found only in living organisms and, being extracted from their native environment, become unstable and lose activity. They have an extreme specificity of action and catalyze strictly defined reactions. This specificity of the action creates a close interconnection of enzymatic reactions that effect metabolism and its strict ordering.

The fat content in many respects depends on the lipid transformation intensity (lipolysis, hydrogenation of unsaturated fatty acids, liposynthesis) in the rumen. $76 \%$ of absorbed lipids go directly to the mammary gland of the cow and $44 \%$ of milk fat has a direct dietary origin.

One of the most valuable nutritional components is milk fat. It does not dissolve in the plasma of milk and is not osmotically active, therefore it is the most 'independent' component of the secret in comparison with its active components - lactose and proteins that determine the colloid-osmotic characteristics of milk. 
The positive and reliable correlation between the content of fat and protein in milk is indicated by and other researchers. The biological role of amino acids is not limited only to their use for protein synthesis - they are involved in many vital processes occurring in the body.

Amino acids - methionine, cystine, cysteine - serve to neutralize a number of toxic metabolic products in the liver. Methionine is one of the donors of methyl groups in the formation of such physiologically important compounds as creatinine, ethanolamine, noradrenaline, nicotinamide, choline, adrenaline and many others. If there is a lack of methionine, the functioning of the liver and kidneys, thyroid and pancreatic glands is disrupted.

Lysine is necessary for the synthesis of hemoglobin of nucleoproteins. This amino acid is exclusively inert in the metabolic processes. Threonine, turning into glycine, is used for the synthesis of protoporphyrin, cholesterol, fatty acids, carbohydrates. In exchange, it is closely related to leucine, but is an antagonist of serine and methionine.

Milk proteins are more valuable than proteins of meat and fish, and are quickly digested. The protein is necessary for the formation of new cells in the human body. Proteins of milk consist of three components: casein, albumin and globulin, which in the raw milk are in a dissolved state. All the milk proteins belong to the wholesome group, containing all the 20 amino acids. Among them, there are 8 essential amino acids that cannot be synthesized in the human body and must be supplied with food, and the absence of at least one of them leads to a metabolic disorder.

Reducing feed consumption in pig production is equivalent to increasing their production. Unlike other biologically active substances, enzyme preparations have a direct effect on the absorption of complex nutrients and promote more efficient use of feed components. Only due to enzymes, nutrients are converted into energy and structural materials necessary for growth, reproduction and other processes in the animal's body. Increasing the nutritional benefits of barley and wheat with enzyme additives is very important, since these feeds occupy a significant proportion in pig rations.

In the experiment conducted on pigs, experimental groups consumed 494.28 - 528.75 energy feed units. Piglets of the control group consumed $46.62 \mathrm{~kg}$ of digested protein, of the 1 st experimental group $-47.78 \mathrm{~kg}$, and of the $2 \mathrm{nd}-49.69 \mathrm{~kg}$.

Based on the $1 \mathrm{~kg}$ of growth, the animals of the 2nd experimental group consumed 5.47 energy feed units and $514 \mathrm{~g}$ of digestible protein, which is 2.2 and $2.5 \%$ less than in the control group.

Thus, the use of the multi-enzyme composition 'Kemzaim W' in the rations of young pigs in the amount of $1 \mathrm{~kg} \mathrm{t}$ of feed promoted their productivity and feed payment in product.

It was also found that the best economic indicators of pork production were obtained in the 2nd experimental group, where 'Kemzaim W' was used in the amount of $1 \mathrm{~kg} / \mathrm{t}$ of feed, as the insignificant increase in the cost of feeds was compensated by an additional gain in live weight. The animals of the 2 experimental group spent 5.47 energy feed units per $1 \mathrm{~kg}$ of growth, which is $2.2 \%$ and $1.6 \%$ less compared with the control and the 1 st experimental group.

Including 'Kemzaim $\mathrm{W}$ ' in the rations in the amount of $1 \mathrm{~kg} / \mathrm{t}$ of feed allows obtaining $81.7 \mathrm{~kg}$ of additional growth, and, correspondingly, more profit than in experimental Group 1 where the additional increase was $24.7 \mathrm{~kg}$.

The cost price of $1 \mathrm{~kg}$ of live weight gain in the $2 \mathrm{nd}$ experimental group was $12.5 \%$ and 9.5\% less than in the control and experimental Group 1 . 


\section{Conclusion}

The inclusion of enzyme compositions in animal rations had a positive effect on the digestibility of nutrients, milk productivity and the composition of cow milk. The use of 'Kemzaim W' in the amount of $1 \mathrm{~kg} / \mathrm{t}$ in rations of young pigs had a beneficial effect on the increase in live weight and average daily growth, the yield of meat, the quality of carcasses and the chemical composition of tissues.

The article presents the results of the study of enzyme compositions in the diets of agricultural mammals. Enzymes not only increase the digestibility of individual components of feed, but also allow increasing the rate of inexpensive raw materials 'rich' in anti-nutritional factors without compromising the health and productivity of the animal. The aim of the study was the use of enzyme compositions in the nutrition of cattle and pigs. Objectives of the study were:

1. To establish the effect of enzyme compositions on the digestibility of nutrients;

2. To study the effect of enzyme compositions on the productivity of cows;

3. To analyze the slaughter and meat qualities of the experimental young fattening pigs.

The animals were divided into control and experimental groups according to the principle of analogue pairs.

In experiments on cows, the digestibility ratios of food nutrients were greater in $f$ the experimental groups receiving the enzyme compositions. They digested more dry and organic matter, crude protein, raw fat, crude fiber and biologically active substances than the control animals. During the first 100 days of lactation, cows of the experimental groups gave $5.5 \%$ and $13.8 \%$ more milk than the control animals. The yield of milk fat in the experimental groups was greater. Thus, including enzyme additives with cellulolytic action in cows' diets positively influenced the digestibility of nutrients in the ration of feeding, milk productivity, and the composition of milk.

In the piglets of the experimental groups receiving the multi-enzyme complex 'Kemzaim W', the digestibility of dry and organic matter improved - the digestibility coefficients were $0.85 \%$ and $0.97 \%$ higher in experimental Group 1 and $2.84 \%$ and $2.66 \%$ $(\mathrm{P}<0.05)$ higher in experimental Group 2, respectively. The animals of the experimental groups were better able to digest raw protein, crude fat and raw fiber. At the end of the experiment the live weight of the pigs in the 2nd experimental group was more than in the $1 \mathrm{st}$ - by $5.3 \%$, and significantly $(\mathrm{P}<0.001)$ more than in the control group - by $7.9 \%$. The highest yield of meat was obtained from the carcasses of the 2 nd experimental group, which is $13.2 \%$ higher $(\mathrm{P}<0.001)$ than in the control. The use of 'Kemzaim $\mathrm{W}$ ' in the amount of 1 $\mathrm{kg} / \mathrm{t}$ in rations of young pigs had a beneficial effect on the increase in live weight and average daily growth, the yield of meat, the quality of carcasses and the chemical composition of tissues.

\section{References}

1. S. Koshelev, O. Ilyasov, O. Romanova, Anthropogenic impact on water bodies within the area of activities of livestock complexes. Ecological Agriculture and Sustainable Development. Editors: Prof. DrLitovchenko Viktor Grigorievich, rector of South Ural State Agrarian University; Prof. DrMirjana Radovic Markovic, South Ural State University, 299-307 (2019)

2. M. L. Dongarra, V. Rizzello, L. Muccio et. al., Mucosal immunology and probiotics Current Allergy and Asthma Reports, 13(1), 19-26 (2013) DOI: 10.1007/s11882-0120313-0 
3. O. V. Kovaleva, N. V. Sannikova, Use of Probiotic Preparations in Waste Waters Cleaning of Agricultural Enterprises. International scientific and practical conference "AgroSMART - Smart solutions for agriculture", KnE Life Sciences, 136--144 (2019) DOI 10.18502/kls.v4i14.5598

4. O. V. Kovaleva, N. V. Sannikova, Microbiological treatment system of storage ponds E3S Web of Conferences: The conference proceedings Innovative Technologies in Environmental Science and Education. Rostov-on-Don: Don State Technical University, 01007 (2019). DOI: https://doi.org/10.1051/e3sconf/201913501007

5. D. M. Lilly, R. H. Stillwell, Probiotics: growth-promoting factors produced by microorganisms Science, 14, 73659, 747-748 (1965) DOI: 10.1126/science.147.3659.747.

6. Mayachkinan.V., Chugunova M. V. Features of soil biotesting for the purpose of their ecotoxicological assessment. Biologiya Vestnik Nizhegorodskogo universiteta im. n. I. Lobachevsky, 1, 84-93 (2009)

7. N. Gruzdeva, D. Eremin, Influence of long-term plowing on water permeability of light-gray forest soils of taiga-forest zone of western Siberia. В сборнике: IOP Conference Series: Earth and Environmental Science. 12th International Scientific Conference on Agricultural Machinery Industry, INTERAGROMASH 012174 (2019)

8. A. S. Motorin, A. V. Iglovikov, Assessment of group composition of peat organic matter for industrial processing In the collection: IOP Conference Series: Earth and Environmental Science. International Conference on Innovations and Prospects of Development of Mining Machinery and Electrical Engineering, IPDME 2018 - Mining Machines, Technologies of Processing and Transportation. Cep. "IOP Conference Series: Earth and Environmental Science" 042016 (2018)

9. D. V. Eremina, D. I. Eremin, Fertility of agrogenic and postagrogenicchernozems of western siberia. In the collection: IOP Conference Series: Earth and Environmental Science. 12th International Scientific Conference on Agricultural Machinery Industry, INTERAGROMASH 012173 (2019)

10. O. R. lyasov, Basic state requirements for environmental aspects to enterprises in the Russian Federation. In the collection: ENVIRONMENTAL management \& audit 1. Tempus project Recoaud. Czestochowa, 118-120 (2016)

11. L. Morozova, I. Mikolaychik, M. Rebezov, N. Fedoseeva, S. Safronov, M. Derkho, V. Kosilov, R. Fatkullin, K. S. Aikumis, IMPROVING THE PHYSIOLOGICAL AND BIOCHEMICAL STATUS OF HIGH-YIELDING COWS THROUGH COMPLETE FEEDING International Journal of Pharmaceutical Research, 12(1), 2181-2191 (2020)

12. N. V. Gaponov, O. P. Neverova, O. V. Gorelik, A. V. Stepanov, Probiotics and animal feed in primates feeding. В сборнике: E3S Web of Conferences 02006 (2020)

13. N. Gavrilova, N. Chernopolskaya, M. Rebezov, D. Moisejkina, I. Dolmatova, I. Mironova, G. Peshcherov, O. Gorelik, M. Derkho, Advanced biotechnology of specialized fermented milk products. International Journal of Recent Technology and Engineering, 8(2), 2718-2722 (2019)

14. A. S. Krivonogova, I. M. Donnik, A. G. Isaeva, K. V. Moiseeva, Methodology for compiling a microbial resistance passport for dairy farms. Agrarian Bulletin of the Urals, 9(200), 42-47 (2020)

15. E. A. Krasnoperova, I. M. Donnik, Yu. A. Yuldashbaev, M. G. Leshcheva, V. N. Kulakov, S. O. Chylbak-ool, Stages of regional food security provision. Bulletin of the National Academy of Sciences of the Republic of Kazakhstan. 6(388), 100-107 (2020) 
16. Kh. E. Flefel, M. O. Gutova, I. M. Donnik, Yu. G. Gribovskiy, Assessment of heavy metals concentration $\mathrm{fe}, \mathrm{zn}, \mathrm{cd}$, and $\mathrm{pb}$ in natural water sources. Agrarian Bulletin of the Urals, 6(185), 44-47 (2019)

17. H. E. Flefel, I. M. Donnik, D. Y. Nokhrin, Chemical composition and water quality of some rivers of the Sverdlovsk oblast (Ural, Russia) Egyptian Journal of Aquatic Biology and Fisheries, 23(4), 659-666 (2019)

18. I. M. Donnik, O. Bykova, A. S. Krivonogova, A. G. Isaeva, O. G. Loretts, A. Baranova, H. Musikhina, A. Romanova, Biological safety of cows' milk under the conditions of technogenic agricultural ecosphere when using biologically active substances. International Transaction Journal of Engineering, Management and Applied Sciences and Technologies, 10(2), 203-209 (2019)

19. Beliaev D, et al. Biosynthesis lipase from the fungus Penicillium hordei isolated from waste fat. E3S Web of Conferences 164, 06029 (2020) doi:10.1051/e3sconf/202016406029 